\title{
Iqtibâs Qur'ani in Syaîr 'Ibârat And Khabar Qiamat The Work Of Abdurrahman Siddiq Al Banjari
}

\author{
Ridhoul Wahidi ${ }^{1}$, Hamam Burhanudin ${ }^{2}$, Najamuddin ${ }^{3}$ \\ \{dhoul_faqoet@yahoo.co.id ${ }^{1}$, hmmudin@gmail.com², Najamuddin@unisi.ac.id ${ }^{3}$ \} \\ Universitas Islam Indragiri Riau, Indonesia ${ }^{1,3}$ \\ IAI Sunan Giri Bojongoro, Indonesia ${ }^{2}$
}

\begin{abstract}
The efforts of the moslemscholars in following the beauty pattern of the Qur'an are by writing expressions in the form of poetry or prose. The science which specifically discusses this is called Iqtibâs, which is an effort carried out by inserting sentences originating from the Qur'an or hadith in a poem / prose without saying that the sentence comes from both. Such definitions are widely agreed upon by balagah (lingusist) experts, but in practice it is found in the work of Shaykh Abdurrahman Siddiq Al-Banjari the Book of Shaykh 'Ibârat and Khabar Qiamat which inserts verses of the Qur'an and hadith and is written that the sentence originates from Qur'an and Hadith. This different pattern is interesting to study in order to find out what the messages and the purpose of mentioning Iqtibâs in them.
\end{abstract}

Keywords. Iqtibâs, al-Qur'an, poem, Abdurrahman Siddiq Al-Banjari

\section{Introduction}

There is no doubt about the beauty of the Qur'anic grammar that is recognized by all the inhabitants of the earth. Poets don't hesitate to quote every sentence in the Qur'an. One of the interesting things from uslub(style) al-Qur'an is that the strands of each verse are beautifully arranged and astounding for those who read them.the Qur'an was revealed in Arabic, where Arabic is the most subtle language of its composition, the most rich in its words, the most complete of its rules and the most literary (Fahruddin, 2017:42). In the historical literature, Arabic has become a clever symbol for those who are skilled in writing poetry, even the Arabs have several markets which are the places for reading poems, including the Ukaz, Majinnah and DzulMajaz markets.Arabic poets from all directions come to those markets to read their proud poems. The best selected poems were written in gold ink and hung from the Kaaba near the idols of their idols (Zayyat, t.t: 34). These verses continued until the time of the Prophet Muhammad sent to bring revelations in the form of the Qur'an, where the Qur'an became a miracle for the challengers who were skilled at making poetry. Among those who oppose the Qur'an by making a rival to the Arabic poems such as the beauty of the Qur'anic uslub are Musailamah al-Kazzab, Thulaihah al-Asadi, al-Aswad al-Ansi, Sajah and others. Efforts to imitate the Qur'an continue until the modern era (not imitating to weaken the Qur'an), but showing the miracles of the Qur'an by inserting verses of the Qur'an or the Prophet's hadith in a poetry / prose, known asiqtibâs. 
Iqtibâs in language means copying or quoting (Suryaningrat, 2017: 397). n terms ofiqtibâs it isinterpreted as a sentence compiled by a poet or a writer by quoting (citation) by inserting a verse of Qur'an or hadith into a series of poems / prose without explaining that the insert is from al- Qur'an or Hadith (Jarim, 2013: 2015).

From the aspect of language (lexical) and the term (terminology) above, the writer does not agree.In the author's opinion, the meaning of iqtibâs is to insert something.If it means copying or quoting as the meaning of the language above, it means moving something to another place without changing, while if it means inserting something it means that maybe moving something that can remain the same (copy) or can change by saying that the insert comes from (al-Qur'an or hadith) or vice versa.In the context of the Qur'an, it becomesiqtibâsqur'aniand if the hadiths are inserted intoiqtibâs hadisi. Iqtibâs according to Majdi Wahbah are inserting a part of the verse of the Qur'an or al-Hadith into prose or poetry, in this insertion activity al-Muqtabis (insertion) is permitted to make changes to al-Muqtabas (verses of the Qur'an and al-hadith) or insert as is without making changes (Majdi, 1984: 56). Iqtibâs is the insertion of a sentence from the Qur'an or hadith, then included in a prose or poem sentence without being explained that the quoted from the Qur'an and al-Hadith (Jarim, t.t: 270).

In this article I will explore iqtibas qur'ani which is a branch of badi' science 'namely muhassinat lafziyah(word beauty), by means of beautifying words in a poem / prose accompanied by inserting verses of the Qur'an. In this case the hipogram is the Qur'an with the reference source of the book being studied is the work of Shaykh Abdurrahman Siddiq AlBanjari in the Book of Shaykh 'Ibarat and Khabar Qiamat.Values of Character Education in Literary Works Literary work is one source of learning that is loaded with values of character education. Literary work as an expression of reality can be explored to find truths that are bidding to be transferred to students. The values of character education in literary works can be conveyed through examples of understanding of life. The values of character education in literary works can be taught through emotive appreciation, and provide opportunities for students and the public to provide assessments and interpretations without having to be lectured

Nation's character education can be interpreted as education that develops cultural values and national character for students. The goal is for students to have values and character as their characters, which in turn can be applied in their lives, as members of the community, and citizens who are religious, nationalist, productive and creative.1 The implementation of character education is oriented to improve the quality of education. The emphasis is placed on the formation of the character and noble character of students who are intact and balanced. With character education, it is expected to be able to form a human who has the ability and character and civilization with a dignified nation according to the mandate of Law No. 20 of 2003. The aim is to develop the potential of students to become human beings who believe in and fear God Almighty, have noble character, be healthy, knowledgeable, capable, creative, independent, and become citizens of a democratic and responsible country. (UUD Number 20 of 2003 concerning the National Education System, Chapter 2 Article 3).

In a study of a number of literary works, especially poems are found loaded with values. In addition to the aesthetic value that can attract the attention of students, also at the same time as unconsciously students are led to enter into the values of truth and goodness. One example, which will be raised in this article is Syaîr 'Ibârat and Khabar Qiamat by Abdurrahman Siddiq Al Banjari. This study is on content analysis, to further take the values of character education in it, which is very likely to be integrated in learning materials. This discussion revolves around the biography of Abdurrahman Siddiq Al Banjari, the themes contained in the verses of Syaîr 'Ibârat and Khabar, and the values of character education in these verses. 


\section{Methodology}

\subsection{Biography Of Shaykh Abdurrahman Siddiq Al-Banjari}

Shaykh Abdurrahman Siddiq al-Banjari was known as a scholar and mufti of Indragiri kingdom. Shaykh Abdurrahman Siddiq al-Banjari was born in a village in Pagar Martapura south borneu, themonth of Rabbi Akhir 1284 Hijrah / August 1857 (Syafei, 1981: 19), which is then called by Tuan Guru Sapat (TGS) (Raihani, 2018: 219) His full name is Sheikh Abdurrahman Siddiq bin Muhammad Afif bin Mahmud bin Jamaluddin al-Banjari (Syeikh Abdurrahman Shiddiq, 1356: 92). His parents named Abdurrahman and while study Mecca, a teacher was named Shaykh Sa'id Bakri Syatha' add the name "Siddiq" because of its noble character and respect the teachers, take notes carefully, then discuss with classmate and practice what has been learned (Yusuf, 1984: 5).

Abdurrahman Siddiq's father was named Sheikh Muhammad Afif bin Kadhi H. Mahmud and his mother named Shafura (Andres, 2017: 5). His mother passed away when Abdurrahman was two months old and was taken care of by his mother's sister named Said and at the age of eight, Abdurrahman had recited Qur'an. After reciting Qur'an, go to the Pagar Martapura Islamic Boarding School which at that time was raised by Haji AbDussamad and studied also toAbdurrahman Muda who was proficient in Arabic. Then he studied with along-time leader in Martapura named Said Wali who latersuggested that Abdurrahman continue his studies to the Holy Land (mecca) (Muthalib, 2019:42-88).

In 1889 Abdurrahman Siddiq left for the Holy Land at the age of 25 years and there was another version saying he left for Mecca in 1887. Siddiq Wahid inMecca Seeking knowledge to moselm scholars who teach religious studies in the Haram. Among his teachers were Sheikh Said Bakri Syatha, Sheikh Said Babasyid, Sayyid Ahmad Zaini Dahlan and Sheikh Muhammad Nawawi al-Bantani (Departemen Agama RI, 1993: 842). In addition Abdurrahman Shiddiq is also active in reciting religion in halaqah-halaqahat the Nabawi Mosque in Medina. Abdurrahman Shiddiq lived in the holy land of Mecca and Medina for seven years, five years studying in Mecca and two years in Medina. With the knowledge gained by Shaykh Abdurrahman Siddiq he had the honor of teaching at the Masjid al-Haram. From this teaching, his students spread to Sumatra, Java, Borneo, Singapore and Malaysia. After about a year he taught at the Masjid al-Haram Mecca, he made the decision to return to Indonesia, considering that in the country at that time there was still a lack of religious teachers. Shaykh Abdurrahman Siddiq returned to Indonesia with Sheikh Ahmad Khathib (Muthalib, 2019:42-88).

When they arrived in Jakarta (Batavia), the two separated to their respective areas. Sheikh Ahmad Khatib headed to West Sumatra and Sheikh Abdurrahman Siddiq to Martapura (South Borneo). A few moments later Shaykh Abdurrahman Siddiq left for Batavia and met Sheikh Ahmad Khathib who was leaving for Mecca. Sheikh Ahmad Khathib advised Syaikh Abdurrahman Siddiq to teach, preach, and compose religious books (Muthalib, 2019:42-88).

In 1899 Syaikh Abdurrahman Shiddiq headed for Bangka Island (where fathersettled and taught). He taught by exploring to the corners of the island, preaching in Surau and mosques with the aim of da'wah to purify Tawheed (aqeedah), where the period was developing mixing between the knowledge of Tawheed and the knowledge of Kebathinan / magician which damaged aqeedah. Khurafat and superstitious stories developed in the community so that they simply believed.This is one of the reasons he wrote the book of Shaykh 'Ibrat and Khabar Qiamat. 


\subsection{Book Of Syaîr 'Ibârat And Khabar Qiamat}

Manuscripts of the Syaîr Ibârat and Khabar Qiamatis a Malay-language text and uses Arabic Malay (Jawi) letters. The number of pages is 186 pages. The number of rows in each page is 20 lines, except on page 186 which amounts to 14 lines. From the information on the cover of the manuscript it can be seen that the manuscript writer was named Abdurrahman Siddiq bin Muhammad Afif al-Banjari. In the colophon section there is also a description of the manuscript writing, namely on the night of Wednesday, 25 Zulkaidah $1332 \mathrm{H} / 15$ October 1914 AD (Novi Setyowati, 2017: 22-23).

Validdata have not been found when this book began to be written, but the information that developed, the Book of Syaîr 'Ibârat and Khabar Qiamat was written before leaving the island of Bangka in 1910 AD The book of Syair' Ibârat and KhabarQiamatconsists of 1857 stanzas or 7428 lines.One of the reasons for this book is to divert people's passion from fairy tales that contradict religious beliefs at the time.

The Book of Syaîr 'IbâratandKhabarQiamatwritten about 107 years ago have been circulating in Bangka, Riau, South Borneo, Singapore and Malaysia.At the end oftheBookSyaîr 'IbâratdanKhabarQiamatwrote that this work is completed in the cap with the will of the author on 9 Sha'ban $1344 \mathrm{H}$ in the printing of Ahmadis in Singapore.

\subsection{Iqtibâs Qur'ani In Syaîr' Ibârat And Khabar Qiamat}

In this article will present the iqtibâs Qur'ani which is called Shaykh Abdurrahman alSiddiq in Shaykh 'Ibrat and Khabar Qiamat.

Written in Syaîr 'Ibârat dan Khabar Qiamat as follows (Abdurrahman al-Siddiq, 1989: 133):

كفد مقعد صدق تمفة كر امةت\# يخدمكين ايت فد هاري جمة

to a maq'adisidqinkaramah place \#that is on Friday دو دقله مريلف دهداثن نعمة \# لاكيفون ككل ددالم لذت

andput them in the dish \# even though it is eternal in delicious دتورنكن اتس مريلك سمو اث \# رحيق مختوم امة نعمثت all of them were descended from them, rahiqimmakhtum, which was very pleasant جفث كستوري امة هارومث \# ممجحهن مريكئيت اكن جفت the kasturi'sjafara is very fragrant \# giving them the chance to jafannya.

There are two characteristics in iqtibâs by Shaykh Abdurrahman al-Siddiq in the verse above, namely the sentence maq'adi sidqin and sentences. The first sentence is mentioned in the Qur'an the 54th letter, surat al-Qamar verse 55, "Meaning:Where the place you like in the side of God in power."

The second sentence isiqtibâs by Shaykh Abdurrahman al-Siddiq is the third faqrah of the word al-Rakhiqim al-Makhtum, this sentence is not the words of the actual poet, but is taken from surat al-Muthafifin (83), verse 25,"They are given a drink from pure khamar(alcohol) which is acted (in place)."

In Syair 'Ibarat and Khabar Qiamat havea verse ini iqtibas by Shaykh Abdurrahman alSiddiq in two different places. This is in the second faqrah (Abdurrahman al-Siddiq, 1989: 144).

$$
\text { سفرت فرمان الله تعالى \# ددالم قر أن يغا مة مليا }
$$

like the word of Allah Ta'ala \# in a very noble Qur'an

$$
\text { يطاف عليهم بصحاف \# من ذهب و أكواب }
$$

yuthâfu 'alaihimbishihâfin \# min zahabinwaakwabin

$$
\text { معناث ايت امتله يقين \# فرمان تو هن رب العالمين }
$$


the meaning is very sure\# the word of God min rabbilalamin.

As for sentences in iqtibâs by Shaykh Abdurrahman al-Siddiq is the third faqrah in the sentence (yuthâfu 'alaihimbishihâfin) and sentences (min zahabinwaakwabin) both of which are taken from al-Qur'an letter 43, surat al-Zukhruf verse 71. In the sentence yuthâfu 'alaihim bishihâfin written in Syair 'Ibarat and Khabar Qiamat follows, "Circulated to them plates of gold, and cups and in heaven there are all things which the heart desires and tastes (eyes) and is eternal in them.". Then another verse is written in verse about eight levels of heaven with iqtibâs sequential as follows:

نماث ايت جمله دلافن \# فرتاما دار الجلال تمفت كبسار ان

The name is eight \# first darul jalal the place of greatness

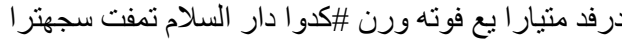

Instead of pearls that are white \# second from the place of prosperity درفد ياقوت جمرلغ يغ جهي \#تثيكث جنة المأوى Instead of theYaqut bright, light درفد زبرجد هيجو ورناث \# درفد مرجان دجاديكن تو هنث Instead of Zabarjad the color is green \# rather than Marjan being used as God جنة الخلد يخكأمفتث\#يره دان كونيخ دوا باكينث

The fourth JannatulKhuldi is \# red and yellow two parts جنة النعيم يخ كليماث \# درفد فيرق فونه وارناث

Jannatunna'im is the fifth \# of white silver in color جنة الفردوس يغةكأنمث \# درفد مس ميره يغدجاديكنث

Jannatul Firdaus is the sixth \# rather than the red one made جنة عدن يخ كتوجه \# \# درفد متيار اساغت فوتيهث

Jannatu'and is the seventh \# \# rather than very white pearls كدلافن دار القرار نماث \#درفد مس ميره يخ دجاديكنث

The eighth name of the darulqarar is made of red gold تمفتث ايت دتغه شركئ\# تتخي درفد سكلين شركئ

The place is in the middle of high heaven than all of its paradise. darussalamprosperous place

The following is an explanation ofiqtibas qur'an about levels of heaven that in iqtibâs by Shaykh Abdurrahman Siddiq in Syair 'Ibarat and Khabar Qiamat. The first Faqrah in the sentence (Dar al-Jalal) there are no verses specifically describing darul jalal. In this verse written the meaning of darul jalal as a place of greatness of Allah. The second Faqrah in the sentence (Dar al-Salam) in iqtibâs from verse al-Qur'an Surat al-An'am verse 27 (Abdurrahman al-Siddiq, 1989: 128), "And if you (Muhammad) saw when they were confronted to hell, then they said:" May we be returned (to the world) and not deny the verses of our Lord, and be believers "(surely you see a touching event)." Faqrah third (Jannatul Ma'wa) (Abdurrahman alSiddiq, 1989: 128). This sentence is in iqtibâs by Shaykh Abdurrahman al-Siddiq citing verse 15 of Surat al-Najm, "On the deckthere is a place of residence." Sentence (Jannat al-Khuldi) in the fourth faqrah in iqtibas right from surat al-Furqan verse 15, (Abdurrahman al-Siddiq, 1989: 128) "Say:" What is this (doom) that is good, or an eternal heaven that has been promised to those who are devoted? "he becomes a reward and a place to return to them? "Sentence (Jannah al-Na'im) in iqtibâs right from the Al-Qur'an letter Luqman verse 8, (Abdurrahman alSiddiq, 1989: 128) "Lo! Those who believe and do good works, for themare glad that they are full of pleasure." Sentence (Jannah al-Firdaus) in iqtibâs right from Surat al-Mukminun verse 11, "(ie) who will inherit Paradise paradise, they abide therein." Sentence (Jannah Adn) in 
iqtibâs right from Surat ash-Shaff verse 12, (Abdurrahman al-Siddiq, 1989: 128)"Surely God will forgive your sins and put you in jannah which flows beneath the rivers;and (put you in) to a good place to live in jannah 'Adn. That's great luck." Sentence (Dar al-Qarar) ini qtibâs right from al-Qur'an letter al-Dukhanverse 51 (Abdurrahman al-Siddiq, 1989: 128) "Indeed those who fearare in a safe place."

\section{Conclusion}

The conclusions that can be drawn from Qur'ani iqtibâs in Syaîr 'Ibârat and Khabar Qiamat by Shaykh Abdurrahman al-Siddiq are found in two forms of iqtibâs. First, iqtibâs which is mentioned that the one quoted is indeed from the Qur'an. Second, do not mention that which is in iqtibas from the Qur'an. The pattern of iqtibas used revolves around the issue of aqeedah as the example presented in the discussion on heavenly matters.

\section{Referenceass}

[1] Abdullah, Syafei, Riwayat Hidup dan Perjuangan Ulama Syekh H.A Rahman Shiddiq, Mufti Indragiri, Jakarta: C.V. Serajaya, 1981.

[2] Ahmad Hasan al-Zayyat, Tarikh al-Adab al-'Arabi Beirut: Dar al-Tsaqafah, t.t

[3] Ali Al-Jarim \&Musthafa Amin, Terjemahan Al-BalaaghatulWaadhihah, cet1, Bandung SinarBaruAlgensindo 1994.

[4] Bahjat, Munjid Musthofa dan Anas Husain an-Naimi, Al-Iqtbas dan wa al-Tanasmin al-Qur'an alKarim liday Majallat al-Adab al-Islami, Semat an International Jurnal Vol 1 No 2, 2013.

[5] Departemen Agama RI, Eksiklopedi Islam, Jilid 2, Jakarta: IchtiarBaru-Van Hoeve, 1993.

[6] Erwin Suryaningrat, Pandangan Ulama Tentang Iqtibas Dengan Ayat Al Qur'an Dan Hadits Nabi Saw, Jurnal At-Ta'lim, Vol. 16, No. 2, Juli 2017.

[7] Fahruddin, Ahmad Hanif, Learning Society Arab Pra Islam (Analisa Historis dan Demografis), Kuttab, Volume 1, Nomor 1, Maret 2017

[8] Halidi, Yusuf, Ulama Besar Kalimantan Syeikh Muhammad Arsyad al-Banjari, Surabaya: Bina Ilmu, 1984.

[9] Majdi Wahbah dan Kamil Muhanddis, Mu'jam al-Musthalahat al-Arabiyat fi al-Lugat aw al-Adab, Beirut: Maktabah Lubnan, 1984.

[10] Muthalib, A., Tuan Guru Sapat; Kiprah dan Perannya dalam Pendidikan Islam di Indragiri Hilir Riau pada Abad XX, Eja Publisher Yogyakarta. 2009

[11] Pransiska, Andres dkk, Peranan Syeikh Abdurrahman Shiddiq Dalam Penyebaran Agama Islam Di Indragiri Hilir. Journal Online Mahasiswa Vol 4 No 1 2017, h.5.

[12] Raihani, Banjarese Islamic Scholars ('Ulema) And Social Transformation In Tembilahan (Preliminary Research), Jurnal Ushuluddin Vol. 26 No.2, July-December 2018

[13] Setyowati, Novi dkk, Eskatologi Islam DalamSyairIbarat Dan Khabar Kiamat JurnalSMaRT Volume 03 Nomor 02 Desember 2017

[14] Shiddiq, Syeikh Abdurrahman Syajarat Al-ArsyadiyyatWa Ma UlhiqaBiha, Singapura :Mathaba'ah al-Ahmadiyyah, 1356

[15] Shiddiq, Syeikh Abdurrahman, Syajarat Al-ArsyadiyyatWa Ma UlhiqaBiha, Singapura :Mathaba'ah al-Ahmadiyyah, 1356

[16] Siddiq, Syaikh Abdurrahman, Syaîr 'Ibârat dan Khabar Qiamat 1989.

[17] Suryaningrat, Erwin, Pandangan Ulama Tentang Iqtibas Dengan Ayat Al Qur'an Dan Hadits Nabi Saw, Jurnal At-Ta'lim, Vol. 16, No. 2, Juli 2017.

[18] Yusuf Halidi, Ulama Besar Kalimantan Syeikh Muhammad Arsyad al-Banjari, Surabaya: Bina Ilmu, 1984. 